\title{
A COMPARISON OF REVERSE OSMOSIS MEMBRANE CLEANING METHODS (U)
}

by J. L. Siler

Westinghouse Savannah River Company

Savannah River Site

Aiken, South Carolina 29808

Other Authors:

This paper was prepared in connection with work done under Contract No. DE-AC09-89SR18035 with the U. S. Department of Energy. By acceptance of this paper, the publisher and/or recipient acknowledges the U.S. Government's right to retain a nonexclusive, royalty-free license in and to any copyright covering this paper, along with the right to reproduce and to authorize others to reproduce all or part of the copyrighted paper. 


\section{DISCLAIMER}

This report was prepared as an account of work sponsored by an agency of the United States Government. Neither the United States Government nor any agency thereof, nor any of their employees, makes any warranty, express or implied, or assumes any legal liability or responsibility for the accuracy, completeness, or usefulness of any information, apparatus, product, or process disclosed, or represents that its use would not infringe privately owned rights. Reference herein to any specific commercial product, process, or service by trade name, trademark, manufacturer, or otherwise does not necessarily constitute or imply its endorsement, recommendation, or favoring by the United States Government or any agency thereof. The views and opinions of authors expressed herein do not necessarily state or reflect those of the United States Government or any agency thereof.

This report has been reproduced directly from the best available copy.

Available to DOE and DOE contractors from the Office of Scientific and Technical Information, P.O. Box 62, Oak Ridge, TN 37831; prices available from (615) 576-8401, FTS 626-8401.

Available to the public from the National Technical Information Service, U.S. Department of Commerce, 5285 Port Royal Rd., Springfield, VA 22161. 
Keywords: Membrane

Fouling, Bacteria,

F/H ETF, Reverse Osmosis, Water Flux, Salt Rejection, Decontamination Factor

Retention Time: Permanent

January 9, 1992

To: D. I. Fish, 773-A

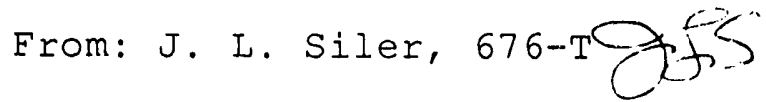

A Comparison of Reverse Osmosis Membrane Cleaning Methods (U)

\section{SUMMARY}

Testing was conducted at TNX to evaluate the reverse osmosis (RO) cleaning methods in use at the $\mathrm{F} / \mathrm{H}$ Effluent Treatment Facility $(E T F)$. The present ETF membrane cleaning protocol involves a lowpressure-no-permeation method using $\mathrm{NaOH}$. This work has examined the effectiveness of the present ETF method, due to the lack of improvement following the cleanings sometimes observed.

This study has evaluated both low pressure (15-20 psi with no permeation) and high pressure (200 psi with permeation) cleaning methods with sequential cleanings using $\mathrm{NaOH}$ and Filmtec Alkaline cleaner. The importance of the cleaning sequence with these two chemicals was also examined.

The amount of flux which could be restored was found to be very dependent upon the sequence in which the cleaning steps were performed. The $\mathrm{NaOH}-t h e n-F i l m t e c$ sequence returned the clean water flux to pre-fouled conditions or better and substantially improved the DFS; whereas, a Filmtec-then-NaOH sequence restored only $90 \%$ of the pre-fouled flux values and only slightly improved the DFs. No significant differences were observed between cleaning operations at low or high pressure.

IWT recommends that the ETF use a two-step cleaning process of $\mathrm{NaOH}$ followed by the Filmtec alkaline cleaner. This cleaning method should restore performance to pre-fouled conditions.

\section{INTRODUCTION}

ETF biofouling problems with the reverse osmosis membranes [e.g., Siler (1991a-1991c)] have been studied and several potential improvements discovered. However, the question of cleaning efficiency at the ETF has not been addressed. In addition, the 
need for additional cleaning capability to maintain or restore the membranes to their designed capacity has also been questioned.

The normal practice in the membrane industry is to clean the membranes using low pressure independent of the cleaning reagent used. This will be sufficient provided that the membrane fouling is on the surface and not down in the pore structure. Low pressure cleaning will not force cleaning solution into the pores and thus subsurface fouling could remain.

An experimental program was implemented to address the question of RO cleaning efficiency. The objective was to evaluate the present method of low-pressure cleaning against high-pressure cleaning and to compare the effectiveness of $\mathrm{NaOH}$ and Filmtec Alkaline Cleaner, which had been shown earlier to be superior to NaOH.

\section{EXPERIMENTAL PROCEDURE}

The basic experimental procedure was outlined in report \#WSRC-RP91-431. Detailed operating instructions can be found in TNX operating procedure \#679T90039.

Severe membrane fouling was achieved using a solution containing salt, sparingly-soluble metals, and $1 . \mathrm{E} 7 / \mathrm{ml}$ bacteria. A flux loss of 20-30\% and a DF loss of over 50\% resulted after processing the bacteria. Two cleaning methods [low pressure (15-20 psi) with no permeation and high pressure (200 psi) with permeation] were tested. Two cleaning reagents ( $\mathrm{NaOH}$ and Filmtec Alkaline Cleaner) were also evaluated. The low- and high-pressure cleaning tests were performed sequentially after fouling the module. Two versions of this experiment were carried out: first the membrane was cleaned with $\mathrm{NaOH}$ then with Filmtec cleaner, and then the reverse order was tested. Each cleaning was performed at $35^{\circ} \mathrm{C}$, and the unit was rinsed and a standard salt test $\left(2,000 \mathrm{mg} / \mathrm{l} \mathrm{NaNO}_{3}\right)$ was performed.

\section{RESULTS AND DISCUSSION}

A summary of the cleaning tests is given in Figures 1-4. It can be seen in Figure 1 that the $\mathrm{NaOH}$ cleaning successfully restored the water flux. However, the flow-averaged DF (Figure 2) was only partially restored by caustic cleaning. The DFs increased from 30 to 80 and 20 to 35 for water recoveries of 0 and $90 \%$, respectively. A low-pressure Filmtec Alkaline Cleaner cycle was required to restore the DF performance. Here the DFs increased to 117 and 50 at 0 and $90 \%$ water recovery, respectively. Bacterial adhesion evidently remained after cleaning the membrane with caustic and Filmtec cleaner was required to completely restore performance.

Cleaning in the reverse order, Filmtec cleaner followed by NaOH, was not as successful. It can be seen in Figure 3 that this methodology was not as effective at restoring performance, as a 
$10 \%$ flux loss remained. Also, as can be seen from Figure 4, the flow-averaged DES only increased from 35 to 60 and 45 to 65 at water recoveries of 0 and $90 \%$, respectively. A second cleaning with $\mathrm{NaOH}$ restored the DF.

The differences observed in the cleaning sequences most likely stem from the fact that the membrane foulant matrix is extremely complex. The presence of both colloidal inorganic hydroxides and a bioslime results in a foulant with strong adhesive tendencies. This foulant would require breakdown of the inorganic colloicis on which the bioslime is adsorbing onto. The $\mathrm{NaOH}$ appears to successfully dissolve the hydroxides into a form with reduced adhesion. This allows the Filmtec cleaner to attack the bioslime, and hence the membrane is restored to pre-fouled conditions. The Filmtec cleaner does not have the ability to modify the inorganic portion of the foulant and thus cannot reach all of the bioslime present on the membrane siufface. The same result would probably occur if an acid cleaner (e.g., oxalic acid) were used prior to the Filmtec Cleaner.

\section{CONCIUSIONS AND RECOMMENDATIONS}

The RO bacterial fouling can be restored by a two-step cleaning process: cleaning the membrane with $\mathrm{NaOH}$ followed by Filmtec Alkaline Cleaner. A second cleaning is required to restore salt DE.

IWT recommends that the membranes at the ETF be cleaned via the same process. Approximately 20-50\% improvement in salt DF can be expected, based on the lab-scale tests. Complete restoration of the water flux would also be anticipated.

\section{QUALITY ASSURANCE}

The work described in this report was performed according to the guidelines in the SRS QA manual. The data collected during these tests were recorded in laboratory notebook \#WSRC-NE-90-257.

\section{REFERENCES}

Siler, J. L., "The Influence of Bacteria on Reverse Osmosis Performance at the $\mathrm{F} / \mathrm{H}$ Effluent Treatment Facility - A Preliminary Investigation(U) ", WSRC-RP-91-431, April 10, 1991.

Siler, J. L., "The Effect of Bacteria and Low Concentrations of Sparingly-Soluble Inorganics on Reverse Osmosis Performance at the F/H Effluent Treatment Facility(U)", WSRC-RP-91-780, August 1, 1991 .

Siler, J. L., "Remediating Biofouling of Reverse Osmosis Membranes(U) ", WSRC-RP-91-1059, October 22, 1991. 


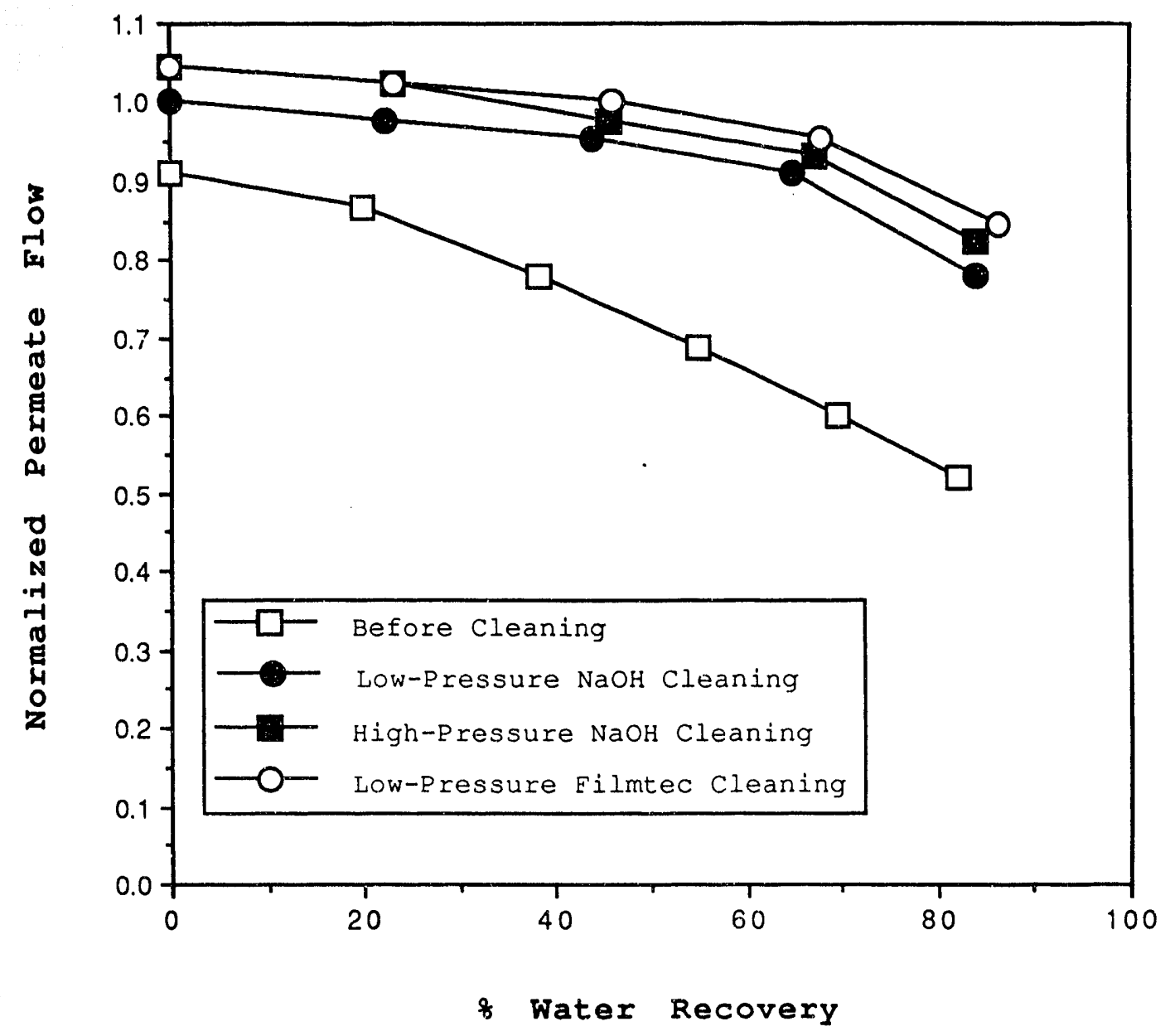

Figure 1. Wator Flux Data Resulting from Cleaning with NaOH Followed by Filmtec Alkaline Cleaner. 
D. I. FISH

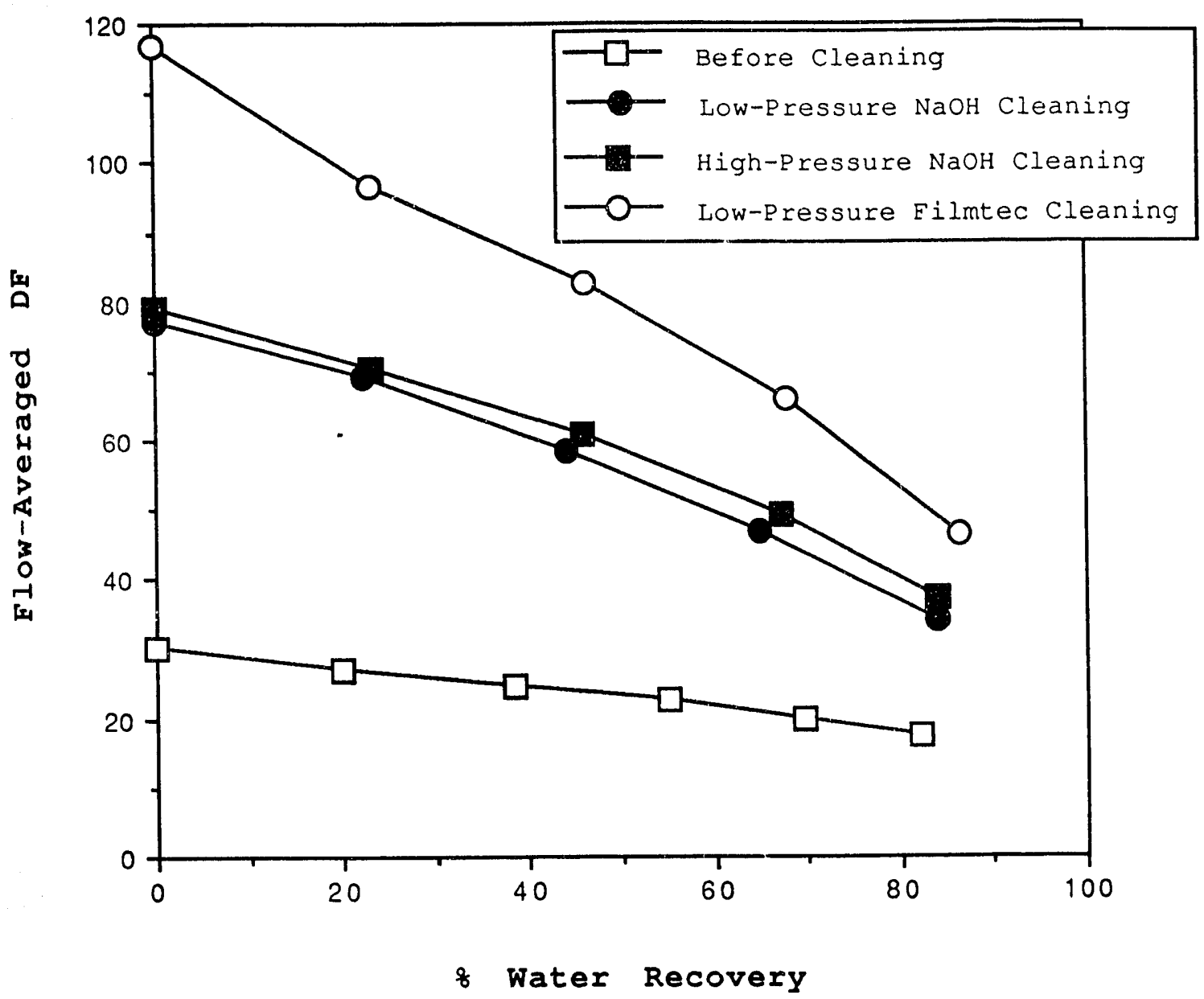

Figure 2. Flow-Averaged DF Improvements Resulting from cleaning with NaOH Followed by Filmtec Alkaline Cleaner. 


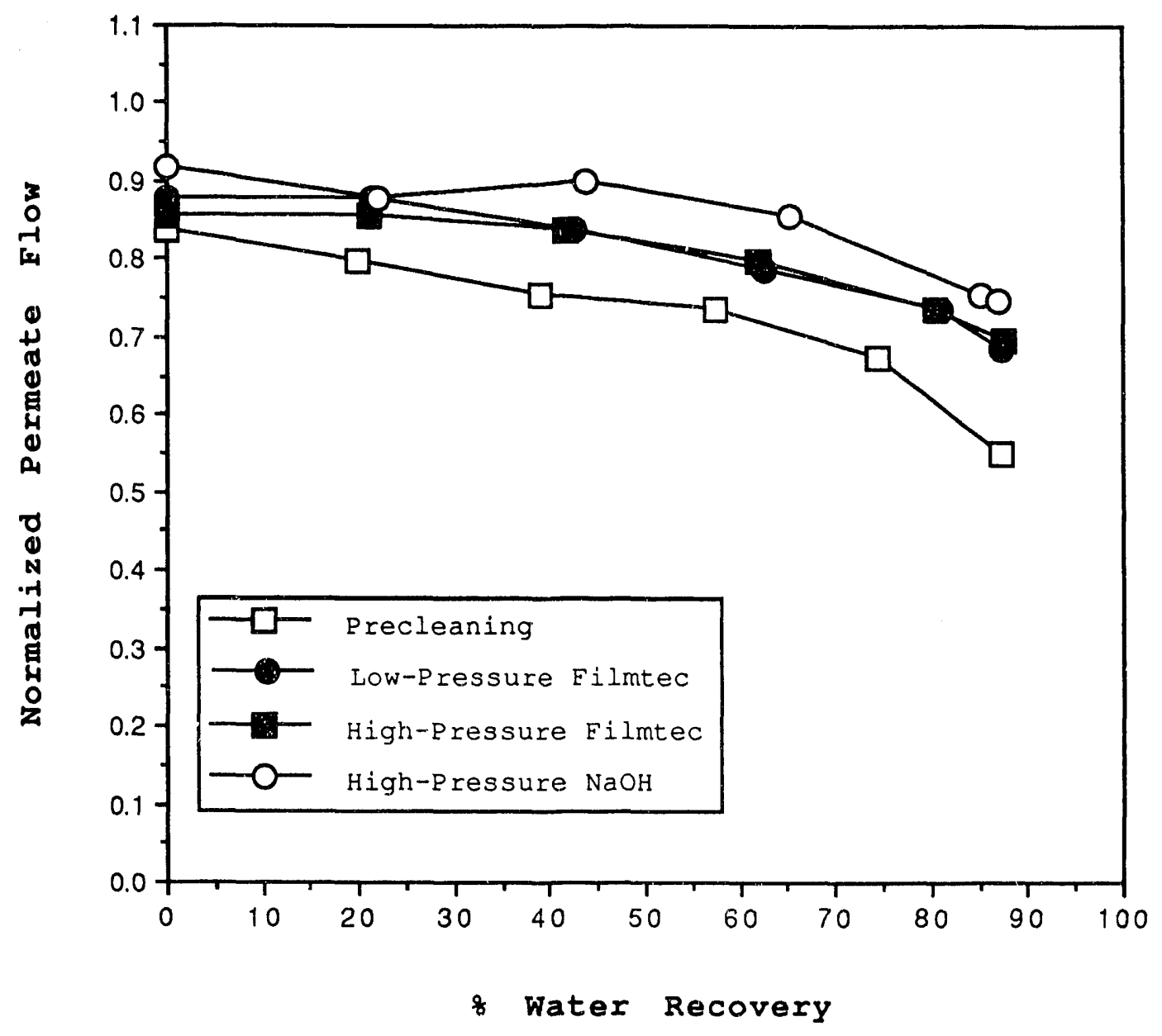

Figure 3. Water Flux Data Resulting from Cleaning with Filmtec Alkaline Cleaner Followed by NaOH. 


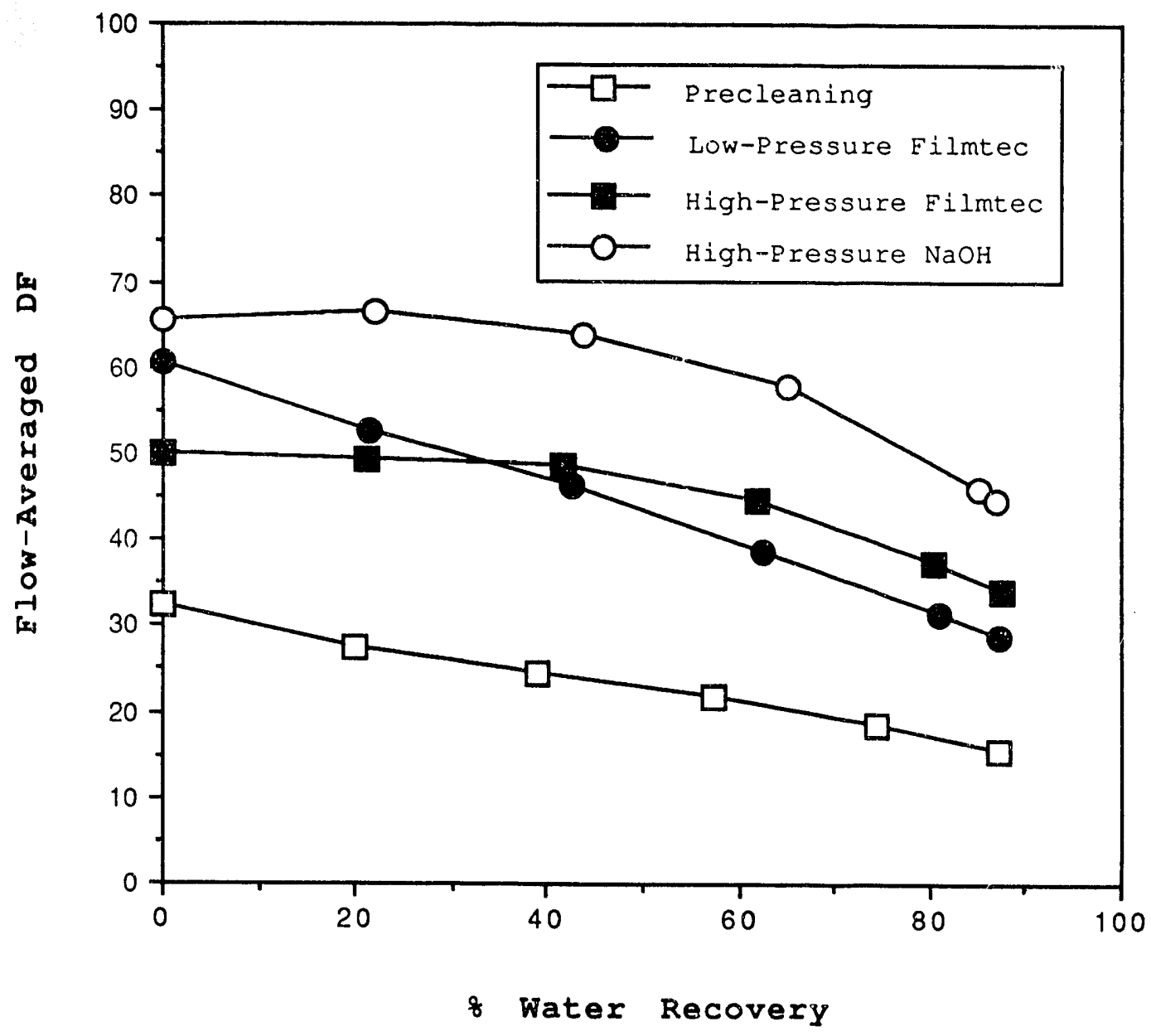

Figure 4. Flow-Averaged DF Improvements Resulting from Cleaning with Filmtec Alkaline Cleaner Followed by NaOH. 

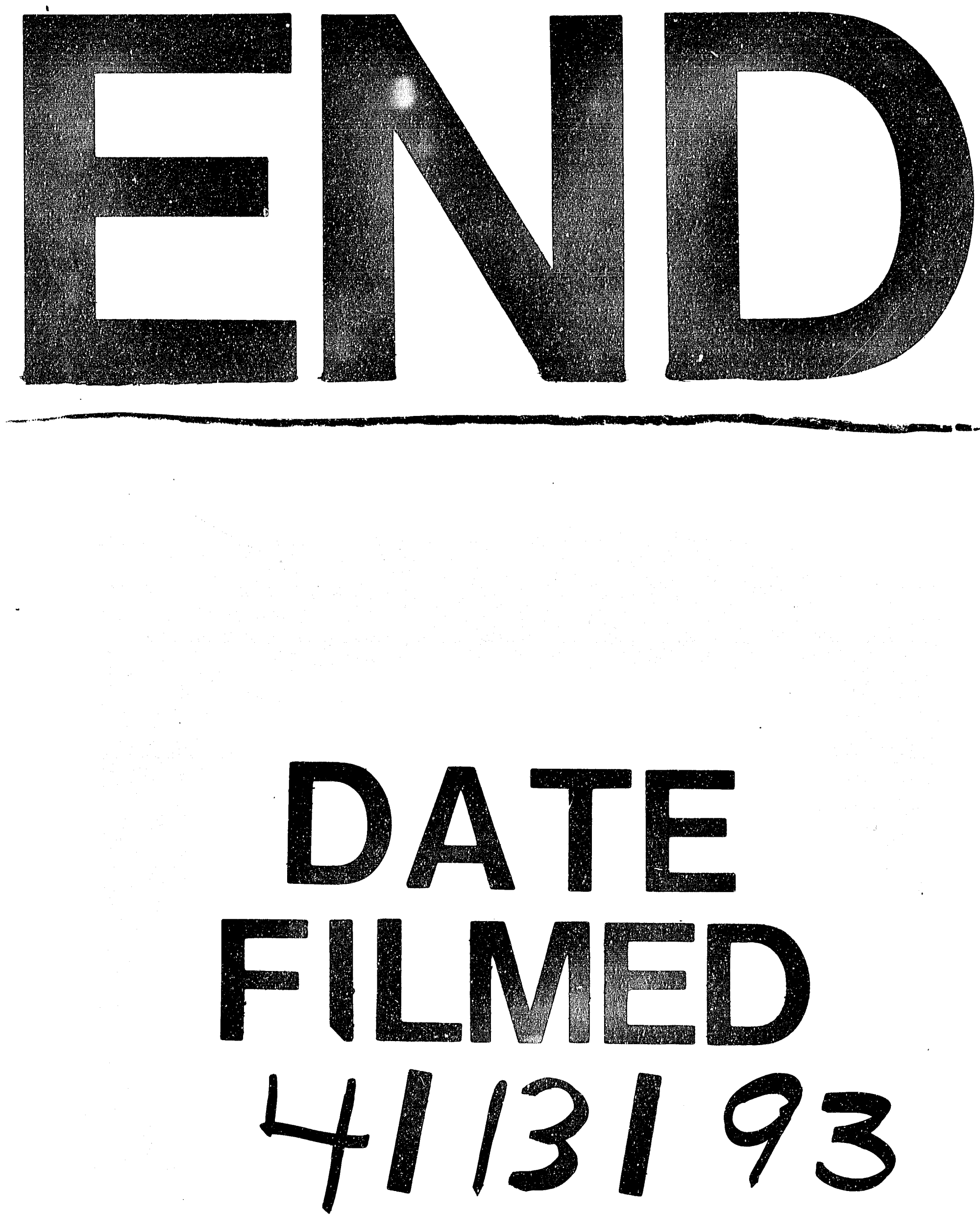
